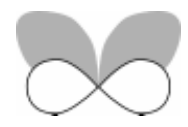

\title{
Ecological and biogeographical implications of Yellow-Legged Gulls (Larus cachinnans Pallas) as seed dispersers of Rubia fruticosa Ait. (Rubiaceae) in the Canary Islands
}

Manuel Nogales*, Félix M. Medina, Vicente Quilis and Mercedes González-Rodríguez Departamento de Biología Animal (Zoología), Universidad de La Laguna, 38206 Tenerife, Canary Islands, Spain

\begin{abstract}
Aim Few data sets exist on the role of gulls as seed dispersal agents. Our purpose is to quantify the number of seeds dispersed, to assess damage to the seeds regurgitated and those expelled via cloaca, to check for possible differences in seed viability and germination rates, to study the seed retention time, and to evaluate gulls as adequate dispersal agents throughout the Canary Islands and for the colonization of this archipelago by this plant species (or its ancestor), from Africa.
\end{abstract}

Location This study was developed in 'Los Islotes', a small archipelago located off the northern part of Lanzarote Island (Canaries).

Methods We counted the number of seeds in each pellet and dropping collected and we measured and weighed them. Seed viability and germination from the three treatments (plants, pellets and droppings) were studied. Gut pass time (GPT) was assessed in two gulls by using glass beads (similar in size with Rubia fruticosa Ait. seeds). We employed a combination of univariate and bivariate statistical tests to analyse the data.

Results From 81 pellets and 84 droppings, we extracted a total of 60,679 seeds $(48,460$ and 12,219 , respectively). Data obtained in the GPT experiments show that a similar number of seeds are defecated and regurgitated. No externally damaged seed was observed and the majority were viable, giving more than $95 \%$ in all treatments (seeds from plants, droppings and pellets). Most seeds on these treatments showed germination rates of over $80 \%$, verifying the importance of the gulls as legitimate dispersers of this Macaronesian endemic plant species. Taking into account that the gulls' flight cruise speed is about $31-40 \mathrm{~km} \mathrm{~h}^{-1}$ and mean GPT of these birds is between 9.51 and $16.92 \mathrm{~h}$, they could cover a distance between 295 and $677 \mathrm{~km}$ before expelling the seeds. This distance is well within the range of colonization of the different islands of the Canaries and the neighbouring archipelagos of Salvages and Madeira from the north-west of Africa, where the ancestor of this plant may have originated.

Main conclusions The results support the idea that gulls could have been one of the main agents responsible for the movement of $R$. fruticosa seeds among the islands of the Canaries and for the colonization of the Macaronesian archipelagos from Africa. Furthermore, this study suggests that gulls are generalist feeding seabirds with high capacity for seed transport and high long-distance power displacements, could have played a more important role than that currently recognized by most authors, in the colonization of oceanic islands by some plants whose genetic origins were located at long-distances.

\footnotetext{
*Correspondence: Departamento de Biología Animal (Zoología), Universidad de La Laguna, 38206 Tenerife, Canary Islands, Spain. E-mail: mnogales@ull.es
} 


\section{Keywords}

Larus cachinnans, Rubia fruticosa, seed dispersal, seed viability and germination, colonization of islands, Canary Islands.

\section{INTRODUCTION}

The diet of the Yellow-Legged Gull (Larus cachinnans Pallas) and related gulls has been considered as widely omnivorous in the Palearctic region (Cramp \& Simmons, 1983; Götmark, 1984). Most studies carried out on its diet have reported the important presence of fish (Andersson, 1970; Witt et al., 1981; Hillström et al., 1994) and marine invertebrates (Spaans, 1971; Sueur, 1990; Munilla, 1997). Furthermore, they show a great capacity to obtain food derived from human activities (Furness \& Monaghan, 1987), including very often both anthropogenic rubbish (Monaghan, 1977; Verbeek, 1977; Mudge \& Ferns, 1982) and fishery waste (Furness et al., 1992; Oro et al., 1995). Some analyses have been made on the diet in the Macaronesian islands, with the importance of Myctophiformes fish noted in the Azores (Hamer et al., 1989), seabirds (mainly small petrels) in Salvages (Mougin \& Stahl, 1981) and in some colonies in the Canaries, the food spectrum is rather varied, as occurs in Timanfaya National ParkLanzarote (Concepción, 1992) and at Alegranza (Jorge et al., 2000).

Although most of the gull's diet is based on fish, marine invertebrates and rubbish, some studies have reported important quantities of vegetable material in the pellets of this species and related gulls (Gillham, 1952; Harris, 1965; Andersson, 1970; Nogales et al., 1995a). However, the presence of fruits in the diet of gulls is quite scarce in most of their geographical range (Cramp \& Simmons, 1983). Only some authors have reported the role of gulls as dispersers of wild seeds (Ridley, 1930; Gillham, 1952; Morton \& Hoggs, 1989; Cortés, 1994; and references therein). Most of these studies are largely based on descriptive information and mention the presence of a number of different seed plant species in gulls' pellets, but the authors have been reluctant to interpret this biological phenomenon in the context of plant-animal interaction. Furthermore, most studies carried out on seed dispersal systems have been developed with small or medium-sized birds (see reviews of Moermond \& Denslow, 1985; Snow \& Snow, 1988; Jordano, 1992; Herrera, 1995; and references therein) and some of them have focussed on generalist bird species of large size that show a great capacity of seed transport and a high longdistance power displacement (e.g. Morton \& Hoggs, 1989; Nogales et al., 1999).

Biogeographers have engaged in an ongoing controversy about how plants colonize oceanic islands. Suggested means of dispersal include ancient land bridges, sea currents, jet streams, seed water flotation, rafting, air flotation, or transport by vertebrates, mainly birds (e.g. Ridley, 1930; van Steenis, 1962; Carlquist, 1965, 1967; Whittaker, 1998; Shilton et al., 1999). Various authors have supported the intervention of birds as dispersers of several plant species, and these vertebrates possess the suitable characteristics (Carlquist, 1965, 1974; Proctor, 1968; Porter, 1976; Valdebenito et al., 1990; Whittaker \& Jones, 1994). However, this process is very difficult to evidence; and faced with this difficulty, and in order to gain insight on this matter, many researchers have presented several arguments in the attempt to demonstrate how birds must have participated in the movement of seeds. These arguments often are based on indirect evidence such as the design of the fruits (Carlquist, 1965, 1967; Porter, 1976; among others) or the hierarchical ecological links of plants with animals (Bush \& Whittaker, 1991).

In this contribution, we explore the plausibility of YellowLegged Gulls acting as legitimate seed dispersers of the Macaronesian endemic plant (Rubia fruticosa Ait., Rubiaceae) across the islands of a small archipelago, known as 'Los Islotes' or 'Archipiélago Chinijo' (thereafter Los Islotes), located in the north-eastern part of the Canaries near to Lanzarote Island (Fig. 1). This archipelago offers a microcosm of how seed dispersal takes place. This model could be applied at a larger scale over a longer time-span. In this paper, we address five main targets: (1) to study the importance of the Yellow-Legged Gull as seed dispersal agent of $R$. fruticosa, (2) to assess the damage to the seeds regurgitated and those expelled via cloaca, (3) to check for possible differences in seed viability and germination rates exposed to different dispersal treatments (directly collected from plants, gull pellets and gull droppings), (4) to study the seed retention time inside the gut of the gulls, (5) to evaluate the likelihood that historically this gull was an adequate dispersal agent throughout the Canary Islands and for the colonization of this archipelago, by this plant species (or its ancestor), from the African continent.

\section{STUDY AREA}

The Canarian archipelago $\left(27^{\circ} 37^{\prime}-29^{\circ} 25^{\prime} \mathrm{N}\right.$ and $13^{\circ} 20^{\prime}-$ $29^{\circ} 25^{\prime} \mathrm{W}$ ) is of volcanic origin and is located off the Atlantic coast of north-west Africa, from which it is approximately $100 \mathrm{~km}$ at the closest point (Fuerteventura). This study was conducted in a small archipelago located off the northern part of Lanzarote Island (Los Islotes), which is composed of five islets: La Graciosa $\left(27.4 \mathrm{~km}^{2}\right)$, Alegranza $\left(10.2 \mathrm{~km}^{2}\right)$, Montaña Clara $\left(1.3 \mathrm{~km}^{2}\right)$, Roque del Este $\left(0.064 \mathrm{~km}^{2}\right)$ and Roque del Oeste $\left(0.016 \mathrm{~km}^{2}\right)$ (Fig. 1). Miocene volcanic activity started around $15 \mathrm{Ma}$ in Lanzarote, forming a succession of basaltic lavas and pyroclastic flows; this period 


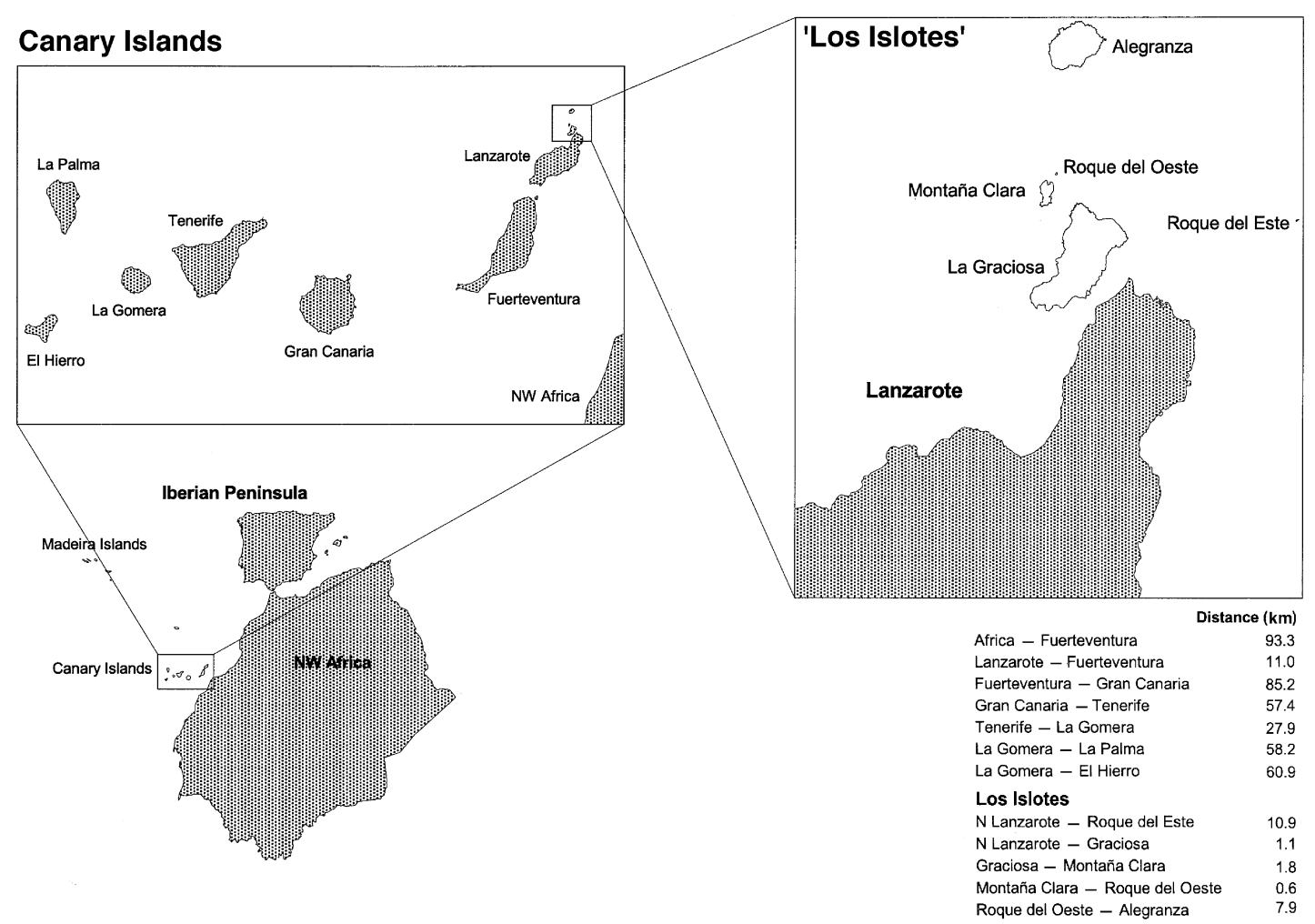

Figure I Map of the Canary Islands and situation of Los Islotes.

includes five separate volcanic edifices that form the islets of Los Islotes (Coello et al., 1992). The eastern Canary Islands (Fuerteventura, Lanzarote and surrounding islets) were joined during the glacial periods on several occasions, the most recent being 18,000 and 12,000 years ago (GarcíaTalavera, 1997). As occurs in the rest of the lowlands of the Canary Islands, the temperature in Los Islotes ranges around $21{ }^{\circ} \mathrm{C}$ and rainfall does not surpass $200 \mathrm{~mm} \mathrm{year}^{-1}$. The vegetation is made up of a sparse xerophytic shrubland. These islands harbour some of the main colonies of seabirds and raptors of the Canaries and represent one of the best places for observing the passage of migratory birds, with more than 60 species having been recorded on Alegranza alone (Martín \& Nogales, 1993). All the islands are uninhabited except La Graciosa where approximately 650 people live (most of them employed in fishing). This archipelago together with 'Riscos de Famara' has been designated as a natural park.

The main part of this study was carried out in Roque del Este, the eastern-most component of the archipelago located at $10.9 \mathrm{~km}$ off Lanzarote. It consists of a small volcanic cone whose maximum altitude is $84 \mathrm{~m}$ a.s.l. (El Campanario) and is badly eroded, in part because it was the target of military manoeuvres by the armies of several countries until the 1970s when an expedition from the Universidad de La Laguna and ICONA prompted the end of these destructive practices. The vegetation is composed of 11 plant species: Zygophyllum fontanesii Webb et Berth. (Zygophyllaceae),
Mesembryanthemum crystallinum L. and M. nodiflorum L. (Aizoaceae), Salsola oppositifolia Desf., Chenopodium murale L., Patellifolia patellaris (Moq.) S., F.-L. et W., Suaeda vera Forssk. ex J. F. Gmel. and Chenoleoides tomentosa (Lowe) Botsch. (Chenopodiaceae), Sonchus bourgeaui Sch. Bip. (Compositae), Lycium intricatum Boiss (Solanaceae) and R. fruticosa.

\section{NATURAL HISTORY OF THE SYSTEM}

Rubia fruticosa is an endemic plant of some Macaronesian archipelagos (Canaries, Salvages and Madeira). It is distributed throughout the Canary Islands, including the islets of Alegranza, Montaña Clara and Roque del Este where it is rather scarce. The plant $(\approx 0.5-1 \mathrm{~m}$ plant cover) can reach about $1.5 \mathrm{~m}$ in height and the fruits are translucent berries (average length $7.5 \mathrm{~mm}$; diameter $5.6 \mathrm{~mm}$; fresh weight $0.2 \mathrm{~g}$; dry weight $0.037 \mathrm{~g}$; water content $81.5 \%$; mean number of seed per fruit 1.4 ; individual seed weight $8.2 \mathrm{mg} ; n=40$ fruits; Nogales et al., 1999). This biotype (characteristic of the larger island populations) contrast with the stunted plants existing in Los Islotes $(\approx 25-30 \mathrm{~cm}$ high and diameter plant cover). Rubia fruticosa and L. intricatum are only local plants that produce fleshy fruits. In the lowlands of the Canaries, fruits of $R$. fruticosa are consumed by several vertebrates, including lizards (Barquín et al., 1986; Valido \& Nogales, 1994; Valido, 1999), birds (Nogales et al., 1999; N. Trujillo, 
pers. comm.) and introduced mammals (Nogales et al., 1995b).

Larus cachinnans is distributed from Eastern Europe, all Mediterranean, Iberia and Macaronesian islands (Azores, Madeira, Salvages and Canaries). It is the only regularly breeding species of gull in the Canaries. The total gull population of the archipelago was estimated in 1987 at about 4000-4700 breeding pairs, and the number on the islets varied (Alegranza: about $35-40$ breeding pairs, Montaña Clara: 300; Roque del Este: 40; Roque del Oeste: perhaps one pair; La Graciosa: no breeding records exist although it is present; Delgado et al., 1991). This gull and the plant are very abundant and well distributed in all the islands, coinciding widely in their geographic range in this archipelago.

\section{MATERIAL AND METHODS}

Fieldwork was conducted on Roque del Este in 1997 and 1998. We stayed on this small islet for 2 days in 1997 (30 April-1 May) and 6 days in 1998 (28 May-2 June). During these expeditions we collected a total of 81 recent pellets and 84 droppings from gulls and we counted the number of seeds in each sample (Table 1). We prospected all the surface of Roque del Este and we individually stored the samples (pellets and droppings) in aluminium foil and extracted the seeds manually.

Because of the fact that plants of $R$. fruticosa from Roque del Este consist in dwarf forms and fruit production is very scarce when it occurs, to perform germination experiments, it was necessary to collect seeds from plants on the neighbouring island of Lanzarote. To test possible differences in the germination curves from seeds obtained directly from plants, pellets and droppings, an experiment was performed using a greenhouse. Before planting, each seed was measured (diameter) and weighed in order to study any possible relationships between these metrics and the germination process. Seeds from plants were collected, in May 1997, from approximately 100 different plants in four localities on Malpaís de La Corona, on the neighbouring island of Lanzarote. The largest population of this plant species on this island is located in Malpaís de La Corona and it is the nearest nucleus to Los Islotes, therefore, it is presumably the place where the gulls consume most of their fruits. Seeds ( $n=208$ per treatment) were sown independently in a standard substrate (50\% turf and $50 \%$ forest soil) and the experiment was followed daily during $3 \frac{1}{2}$ months.

Table I Number of Rubia fruticosa Ait. seeds obtained from pellets $(n=81)$ and droppings $(n=84)$ of Larus cachinnans Pallas in Roque del Este, during 1997 and 1998

\begin{tabular}{llclc}
\hline & \multicolumn{4}{l}{ Number of seeds } \\
\cline { 2 - 5 } Treatment & Mean & Median & SD & Range \\
\hline Pellets & 598 & 537 & 285.1 & $150-1693$ \\
Droppings & 146 & 97 & 150.0 & $15-691$ \\
\hline
\end{tabular}

We watered the seeds every 2 days and the night-day light period condition was similar to that found in the study area. In order to estimate the possible bias caused by the seed dormancy effect, a comparison of viability of randomly selected seeds from the three treatments (plants, pellets and droppings) was simultaneously carried out. Six-hundred and sixty-two seeds (plants: 217, pellets: 227, droppings: 218) were cut down the middle and included in a bio-indicator substance (2, 3, 5 triphenyl tetrazolium; Scharpf, 1970). Seeds were previously immersed in ethanol (70\%) for $15 \mathrm{~s}$ and put into pure water for $8 \mathrm{~h}$.

To learn the gut pass time (hereafter GPT) of the R. fruticosa seeds, we held two gulls for 4 days in individual cages $(80 \times 50 \times 90 \mathrm{~cm})$ where the presence of pellets or defecations was easy to see and record. Gulls were each hand force-fed with 750 glass beads (similar in size to $R$. fruticosa seeds), a number that corresponded with the sum of the means of seeds counted in a pellet (about 600) and a dropping (150) (see Table 1) together with some food. Because characteristics of food consumed affect the speed at which food is moved through the gut (Clench \& Mathias, 1992), and considering the omnivory of gulls, we carried out two different experiments, simulating two types of diets: (1) carnivore (sardines) and (2) vegetarian or frugivore (ripe grapes). This last trial was important because of the high composition of fleshy fruits in the gull's diet in Roque del Este during the spring. We made four feeding trials per animal (two with the carnivore diet and two with the vegetarian diet) using in each case a different colour of beads to separate the experiment types. Feeding trials were performed every $12 \mathrm{~h}$, the first in the morning and the second in the afternoon. Cages were examined every hour and pellets or faeces were visually recorded; all individuals had ad libitum access to the diet previously mentioned, water and grit. GPT was defined as the average time from consumption until appearance in the pellets or droppings of all glass beads regurgitated or defecated in both treatments (carnivore and vegetarian diet).

\section{RESULTS}

\section{Diet and importance of moved seeds}

Different types of food items were identified from the gull pellets, including fish bones, small Coleoptera remains (Curculionidae and Tenebrionidae), gastropod shells, one seed of $P$. patellaris (Chenopodiaceae) and inorganic material (glass, grit, aluminium foil and plastic). However, all the pellets and droppings contained seeds from R. fruticosa and most of them were composed entirely of these seeds. We counted a total of 48,460 seeds from this plant species in the 81 gull pellets and 12,219 seeds in the 84 dropping samples collected in Roque del Este. The mean number of seeds was about five times larger in pellets than in droppings, and statistical differences were recorded (Mann-Whitney test, $Z=9.81, P<0.001$; Table 1$)$. However, the defecation rate was clearly higher than regurgitation rate (see data on GPT experiments). 
Table 2 Size and weight of Rubia fruticosa seeds collected on the plants and extracted from the pellets and droppings of Larus cachinnans in Roque del Este

\begin{tabular}{|c|c|c|c|c|c|c|c|c|c|}
\hline & \multicolumn{3}{|l|}{ Plants } & \multicolumn{3}{|l|}{ Pellets } & \multicolumn{3}{|c|}{ Droppings } \\
\hline & Mean & SD & $n$ & Mean & SD & $n$ & Mean & SD & $n$ \\
\hline $\begin{array}{l}\text { Diameter } \\
(\mathrm{mm})\end{array}$ & 2.33 & 0.22 & 208 & 2.47 & 0.24 & 208 & 2.50 & 0.26 & 208 \\
\hline $\begin{array}{l}\text { Weight } \\
\text { (g) }\end{array}$ & 0.0062 & 0.0015 & 208 & 0.0058 & 0.0015 & 208 & 0.0059 & 0.0014 & 208 \\
\hline
\end{tabular}

\section{Seed traits}

The size and weight of the seeds found in the pellets, droppings and those extracted directly from fruits collected on the plants are shown in Table 2. The diameter of seeds collected from plants was smaller than that of seeds from the other two treatments (ANOVA, $F=28.92, P<0.001$ ), and no significant differences were recorded between seeds from pellets and droppings. However, the smallest seeds from the plants were heavier than those obtained from pellets and droppings (anova, $F=4.03, P=0.018$ ), and no differences were detected between the last two $(P>0.05)$. To calculate the lost weight of the seeds expelled via pellets or droppings it was necessary to consider only the seeds collected on the fruit plants because they had not been consumed. Therefore, and taking into account only these seed plants, we performed a correlation (Pearson correlation coefficient, $\left.r_{p}=0.81, P<0.001\right)$ and a posterior regression analysis (Weight $=0.0057$ Diameter $-0.0072 ; R^{2}=0.67$ ). Then, we substituted in this formula the mean diameter of the seeds obtained from the pellets and droppings in order to calculate the theoretical weight for both types of seeds separately. From the differences between these results and those observed in the pellets and droppings, we noted that the consumed seeds lost about $15.7 \%$ (in the case of the droppings) and $14.7 \%$ (in the pellets) of the weight. The weight probably was lost to dehydration.

\section{Seed viability, germination and GPT experiments}

The presence of broken seeds of $R$. fruticosa was negligible in the three treatments and we performed several tests of viability and germination for all of them (Table 3). More than $95 \%$ of seeds were viable in all treatments, and no statistical differences were recorded (Likelihood ratio test, $G=3.24, P=0.19)$. In the germination trials, germination

Table 3 Seed rates of viability and germination of Rubia fruticosa for the three treatments (seeds from plants, and seeds from pellets and droppings of Larus cachinnans)

\begin{tabular}{lccc}
\hline & Plants & Pellets & Droppings \\
\hline Viable & $210(96.8)$ & $221(97.4)$ & $216(99.1)$ \\
Non-viable & $7(3.2)$ & $6(2.6)$ & $2(0.9)$ \\
Germinated & $170(81.7)$ & $181(87.0)$ & $191(91.8)$ \\
Non-germinated & $38(18.3)$ & $27(13.0)$ & $17(8.2)$ \\
\hline
\end{tabular}

Values are given as number $(\%)$. rates were higher than $80 \%$ in all treatments and significant differences were only recognized between those seeds from plants and from droppings (higher germination percentages in the latter ones) $\left(\chi^{2}=9.24\right.$, d.f. $\left.=1, P=0.002\right)$. Seeds from droppings also germinated earlier than those from pellets and plants (Kolmogorov-Smirnov tests, $K-S=2.29$, $P<0.001$ and $K-S=2.92, P<0.001$, respectively) and seeds from pellets also germinated earlier than those from plants $(K-S=2.21, P<0.001$; Fig. 2$)$.

The only relationship found between the metrics of the seeds and the germination pattern was in seeds collected from plants. These exhibited a direct correlation between weight, size and germination rate (Table 4).

The GPT experiments indicated that seeds remain in the intestinal tract of gulls for a mean of $9.51 \mathrm{~h}(\mathrm{SD}=10.66$, range $=1-47)$ if they are expelled via regurgitation and $16.92 \mathrm{~h}(\mathrm{SD}=11.13$, range $=2-72)$ if they are expulsed via cloaca (Table 5). Despite the small sample size ( $n=2$ gulls), GPT was in both cases (regurgitation and defecation) higher in the feeding trials made with carnivore diet than the herbivore diet. Furthermore, the defecation rate was nine times higher than regurgitation rate $($ mean $=1.20$ per hour, $\mathrm{SD}=1.10$, range $=0-4, n=24 \mathrm{~h}$ vs. mean $=2.7 / 24 \mathrm{~h}$, $\mathrm{SD}=2.3$, range $=0-4, n=96 \mathrm{~h}$, respectively) and the total number of glass beads ejected by the cloaca was similar to the number expelled orally in each feeding trial.

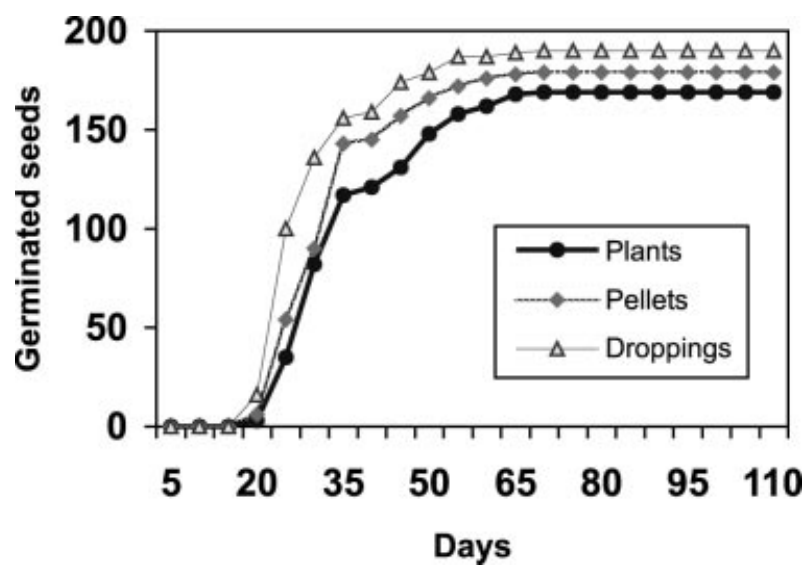

Figure 2 Germination patterns of Rubia fruticosa Ait. seeds obtained from fleshy fruits and Larus cachinnans Pallas droppings and pellets in Roque del Este. 
Table 4 Relationships between seed size and seed weight of Rubia fruticosa on the germination process for the three treatments (plants, pellets and droppings of Larus cachinnans) in Roque del Este. Seeds per each treatment was $n=208$

\begin{tabular}{|c|c|c|c|c|c|c|c|c|c|c|c|c|}
\hline \multirow[b]{3}{*}{ Seeds } & \multicolumn{4}{|l|}{ Plants } & \multicolumn{4}{|l|}{ Pellets } & \multicolumn{4}{|c|}{ Droppings } \\
\hline & \multicolumn{2}{|c|}{ Diameter (mm) } & \multicolumn{2}{|c|}{ Weight (g) } & \multicolumn{2}{|c|}{ Diameter (mm) } & \multicolumn{2}{|c|}{ Weight (g) } & \multicolumn{2}{|c|}{ Diameter $(\mathrm{mm})$} & \multicolumn{2}{|c|}{ Weight (g) } \\
\hline & Mean & SD & Mean & SD & Mean & SD & Mean & SD & Mean & SD & Mean & $\mathrm{SD}$ \\
\hline Germinated & 2.35 & 0.22 & 0.0064 & 0.0015 & 2.47 & 0.23 & 0.0058 & 0.0014 & 2.50 & 0.27 & 0.0059 & 0.0015 \\
\hline Non-germinated & 2.28 & 0.17 & 0.0056 & 0.0014 & 2.45 & 0.30 & 0.0057 & 0.0020 & 2.46 & 0.20 & 0.0059 & 0.0013 \\
\hline Student's test & 1.77 & & 2.66 & & 0.48 & & 0.34 & & 0.74 & & 0.14 & \\
\hline$P$ & 0.079 & & 0.008 & & 0.63 & & 0.73 & & 0.46 & & 0.89 & \\
\hline
\end{tabular}

Table 5 Results of gut pass time experiments performed on two individuals of gulls Larus cachinnans. Each gull was fed 750 glass beads in each of the two treatments

\begin{tabular}{|c|c|c|c|c|c|c|}
\hline \multirow[b]{3}{*}{ Statistical parameters } & \multicolumn{6}{|c|}{ Transit times $(\mathrm{h})$} \\
\hline & \multicolumn{3}{|c|}{ Regurgitation } & \multicolumn{3}{|c|}{ Defecation } \\
\hline & Sardines & Grapes & Total & Sardines & Grapes & Total \\
\hline Mean & 16.86 & 3.63 & 9.51 & 23.63 & 12.17 & 16.92 \\
\hline Median & 22 & 2 & 5 & 22 & 9 & 14 \\
\hline $\mathrm{SD}$ & 11.93 & 3.58 & 10.66 & 12.03 & 7.40 & 11.13 \\
\hline Range & $2-47$ & $1-22$ & $1-47$ & $2-72$ & $5-44$ & $2-72$ \\
\hline
\end{tabular}

\section{DISCUSSION}

\section{The vegetarian component of the diet of gulls}

The spring diet of gulls in Roque del Este was omnivorous, but we emphasize the high frequency and abundance of $R$. fruticosa seeds. Although the diet of L. cachinnans and related species in other areas is based mainly on food of animal origin, the presence of plant material in pellets has often been reported, such as fibre from terrestrial plants (Harris, 1965; Nogales et al., 1995a), commercial seeds proceeding from rubbish dumps (Munilla, 1997), etc. Part of this material, such as grass, is associated in the pellets with the presence of sharp and caustic objects, such as marine invertebrate shells, beaks of cephalopods or elytron of insects, suggesting that the consumption of this poor nutritive food could provide a buffer for these material (Munilla, 1997). These plant fibres may contribute to the formation of pellets, avoiding injuries in the digestive tract, and facilitating the accumulation and posterior expulsion of the indigestible remains (Nogales et al., 1995a).

\section{Seed dispersal by gulls}

The gull consumption of grain and weed seeds has been mentioned (Gillham, 1952; Andersson, 1970, and references therein), and some researchers have pointed out the role of gulls in dispersing plants to islands in temperate latitudes (Gillham, 1956; Morton \& Hoggs, 1989 and references therein). Gillham (1956) cited the presence of 14 seed plant species in the Pembrokeshire Islands of Wales while
Morton \& Hoggs (1989) found a total of 24 different seed plant species ( 21 in pellets and three in droppings) in the Great Lakes (Canada) and most of these species corresponded to weedy plants in both cases. In our GPT experiments, at least half of the $R$. fruticosa seeds were ejected via cloaca, which increases the gut retention time and therefore the potential distance of seed dispersal. Furthermore, the lack of differences in size and weight between seeds from pellets and droppings is probably because of the small size of these propagules, which are able to pass intact through the digestive tract.

Morton \& Hoggs (1989) managed to germinate 19 plant species from seeds that had been ingested by gulls, indicating the legitimate role of these birds as seed dispersers. These data coincide with our results in all three treatments (seeds from fruit plants, pellets and droppings) high viability and germination rates were observed. All seems to indicate that gulls produce a digestive mechanical abrasion on the seed coat causing a probable dehydration effect on the seeds that were ejected by regurgitation or via cloaca. This process was very important for enhancing the speed germination process compared with those seeds collected directly from fruit plants. Although it is known that bigger seeds show a higher germination rate (Silvertown, 1981), this pattern was confirmed in the case of the non-ingested seeds and this tendency was masked when the seeds were consumed by the gulls. Data from the speed of germination indicate that seeds ejected via cloaca or expelled by regurgitation germinated earlier than those from plants. This temporal pattern could have a beneficial effect on the seed germination in arid ecosystems, where rain is unpredictable (see Nogales et al., 
1998; Traveset, 1998). In these environments, seeds must be ready for germination with the arrival of the first precipitations (Izhaki \& Safriel, 1990).

\section{Biogeographical considerations}

The data presented in this contribution strongly support the hypotheses of the gulls as one of the main agents of $R$. fruticosa dispersal, both among the islands of the Canaries and for the colonization of the Macaronesian archipelagos from the African mainland. However and before widely treating this phenomenon, it would be interesting to consider that another potential disperser could be the raven (Corvus corax L.), a species that also eats fruits from this plant species (Nogales et al., 1999). Although this corvid could play a certain role in seed dispersal among islets and islands, its consumption is lower, the population is much smaller and the species shows a more sedentary behaviour pattern (Nogales \& Hernández, 1994, Nogales et al., 1999). It is also interesting to note that lizards from the endemic genus Gallotia have colonized all the islands of the Canaries and they could also have dispersed seeds among them inside the gut, although this means of transport seems to be clearly less frequent than the gulls. Furthermore, Los islotes constitute one of the main places for the passing of migratory birds and some of them are clearly frugivorous (warblers, thrushes, etc.). Therefore, some of these species also could have participated in the colonization of the archipelago by this plant species from the African continent.

As far as we know, the number of seeds (thousands) of $R$. fruticosa dispersed to Roque del Este are much greater than the number of seeds of any plant species moved by gulls in the world. The dispersal of this Rubiaceae also has been observed in the neighbouring islands of Montaña Clara (pers. obs.) and Alegranza (Jorge et al., 2000) but the volume of seeds has been lower. This suggests that L. cachinnans is one of the main agents responsible for the presence of $R$. fruticosa in all the mentioned islets. However, it is important to consider that the eastern Canary Islands (Fuerteventura, Lanzarote and surrounding islets) were joined during the glacial periods on several occasions (García-Talavera, 1997). Therefore, the current distribution of $R$. fruticosa in the islets could have originated as long as 18,000 years ago, and is not wholly the results of dispersal by birds. Nevertheless, the current dwarf form of the plants in these islets, whose fruit production is very scarce when it occurs, suggests that this population has originated from the numerous seeds that are transported every year by the gulls from the neighbouring island of Lanzarote. Furthermore, the spatial distribution of these small plant populations in Roque del Este, Montaña Clara and Alegranza coincides in all cases with those of the main colonies of gulls on these islets. A larger spatial pattern that supports the idea of the gulls as one of the main agents of dispersal of $R$. fruticosa, both among the islets of Los Islotes and the rest of the Canary Islands, is the fact that both the plant and the bird are very abundant and well distributed in all the islands, coinciding widely in their geographical range throughout each island of this archipelago.

The movement of seeds by gulls acquires even greater importance on the western island of El Hierro, where both plant and bird are very widely distributed and the gulls consume a high quantity of fruits and seeds. On this island, many young plants get established after the dispersal process in suitable habitat, while this does not occur on the xerophytic islets of Los Islotes where suitable habitat for this plant is relatively scarce. A clear example can be observed in Roque del Este where despite the arrival of thousands of seeds every year, the population of $R$. fruticosa is only 22 stunted plants. It is very probable that this dwarf biotype is related to the adverse habitat conditions, characterized by high sunshine and salinity, scarce precipitation, and poor soil because of the steep terrain.

According to the GPT results, seeds remain in the intestinal tract of gulls about $9.51 \mathrm{~h}$ if they are regurgitated or $16.92 \mathrm{~h}$ if defecated (general mean of both feeding trials). These data concur quite well with those given by Proctor (1968) for similar seed and bird sizes. Taking into account that the gulls have a cruise flight speed of $31-40 \mathrm{~km} \mathrm{~h}^{-1}$ (Meinertzhagen, 1955; Campbell \& Lack, 1985), they could cover a distance of $295-677 \mathrm{~km}$ before expelling the seeds. The Canaries, Salvages, Madeira, and the NW coast of Africa are all well within this range (Fig. 1). Furthermore, the cruise flight speed from the north-west of Africa to the Canaries is favoured by the NE trade winds, which sometimes reach gale-force. In this regard, Martín \& Lorenzo (2001) mention the presence in Africa (Dakhla, Western Sahara) of gulls ringed in Canaries (Tenerife) and how gulls cross to the islands following ships.

It is important to consider that experimental GPT results obtained during our experiments (in captivity conditions) could be different from those that occur in the wild. However, in a wider geographical context, and considering the maximum GPT value observed in our experiments (72 h) and the fastest cruise flight speed previously mentioned $(40 \mathrm{~km})$, gulls could carry seeds to islands located at $2880 \mathrm{~km}$ distant from the continent. Other genera of Rubiaceae, such as Bobea, Canthium, Coprosma, etc. have been considered to be dispersed by birds in the Pacific Ocean (Gulick, 1932; Carlquist, 1965, 1967). The fleshy, nonfloating fruits of these plants have moderate-sized seeds suitable for ingestion and dispersal by these animals.

In summary, the results of our study of seeds from the gull colony of Roque del Este support the hypotheses that gulls (L. cachinnans) could have been one of the main agents responsible for the movements of $R$. fruticosa seeds among the islands of the Canaries and for the colonization of the Macaronesian archipelagos by this plant from the African mainland. Finally, this study suggests that generalist feeding seabirds with high capacity for seed transport and high power displacements, like the gulls, could have played a more important role than that currently recognized in the colonization of oceanic islands by some plants whose genetic origins were located in distant continental masses. 


\section{ACKNOWLEDGMENTS}

Aurelio Martín shared with us the two expeditions carried out to Roque del Este. Francisco Valdés advised us on all referent to the viability tests. Ignacio Munilla provided important gull references, Elena Mateo collected the plant fruits from Lanzarote and Concepción Nieves gave logistic support during the GPT experiments. Bernard Zonfrillo, Alfredo Valido and Robert Whittaker read and offered very valuable comments and suggestions to improve the manuscript. The Unidad de Medio Ambiente del Cabildo Insular de Lanzarote permitted our access to the islet and gave logistic support, in particular Luis Pascual; and the Unidad de Medio Ambiente del Cabildo Insular de Gran Canaria facilitated the gulls for doing the GPT experiments, particularly Pascual Calabuig and Loly Estévez. The editor (Philip Stott) and two anonymous referees offered all kinds of useful suggestions and comments to improve the manuscript.

\section{REFERENCES}

Andersson, A. (1970) Food habits and predation of an inlandbreeding population of the Herring Gull Larus argentatus in Southern Sweden. Ornis Scandinavica, 1, 75-81.

Barquín, E., Nogales, M. \& Wildpret, W. (1986) Intervención de vertebrados en la diseminación de plantas vasculares en Inagua, Gran Canaria (Islas Canarias). Vieraea, 16, 263-272.

Bush, M.B. \& Whittaker, R.J. (1991) Krakatau: colonization patterns and hierarchies. Journal of Biogeography, 18, 341-356.

Campbell, B. \& Lack, E. (1985) A dictionary of birds. T and A.D. Poyser, Calton.

Carlquist, S. (1965) Island life. The Natural History Press, New York.

Carlquist, S. (1967) The biota of long-distance dispersal. V. Plant dispersal to Pacific Islands. Bulletin of the Torrey Botanical Club, 94, 129-162.

Carlquist, S. (1974) Island biology. Columbia University Press, New York.

Clench, M.H. \& Mathias, J.R. (1992) Intestinal transit: how can it be delayed long enough for birds to act as long-distance dispersal agents? Auk, 109, 933-936.

Coello, J., Cantagrel, J.M., Hernán, F., Fuster, J.M., Ibarrola, E., Ancochea, E., Casquet, C., Jamond, C., Díaz de Téran, J.R. \& Cendrero, A. (1992) Evolution of the eastern volcanic ridge of the Canary Islands based on new K-Ar data. Journal of Volcanology and Geothermal Research, 53, 251-274.

Concepción, D. (1992) Avifauna del parque nacional de timanfaya. ICONA, Madrid.

Cortés, J. (1994) The dragon tree Dracaena draco (L.) L. naturalised in Gibraltar. Revista de Estudios Campogibraltareños, 11, 183-189.

Cramp, S. \& Simmons, K.E.L. (1983) The birds of the western Palearctic, Vol. III. Oxford University Press, Oxford.

Delgado, G., Martín, A., Nogales, M., Quilis, V., Hernández, E. \& Trujillo, O. (1991) Distribution and population status of the Herring Gull Larus argentatus in the Canary Islands. Seabirds, 14, 55-59.
Furness, R.W., Ensor, K. \& Hudson, A.V. (1992) The use of fishery waste by gull populations around the British Isles. Ardea, 80, 105-113.

Furness, R.W. \& Monaghan, P. (1987) Seabird ecology. Blackie \& Son Ltd, Glasgow, UK.

García-Talavera, F. (1997) Las Canarias orientales y vecina costa africana en el Holoceno. Eres (Arqueología), 7, 55-63.

Gillham, M.E. (1952) The distribution of seeds by gulls. Skokholm Birds Observational Report, 1952, 34-35.

Gillham, M.E. (1956) Ecology of the Pembrokeshire Islands. V. Manuring by the colonial sea-birds and mammals, with a note on seed distribution by gulls. Journal of Ecology, 41, 84-99.

Götmark, F. (1984) Food and foraging in five European Larus gulls in the breeding season: a comparative review. Ornis Fennica, 61, 9-18.

Gulick, A. (1932) Biological peculiarities of oceanic islands. The Quarterly Review of Biology, 7, 405-427.

Hamer, K.C., Baber, I., Furness, R.W., Klomp, N.I., Lewis, S.A., Stewart, F.M., Thompson, D.R. \& Zonfrillo, B. (1989) Diet of Yellow-Legged Herring Gull Larus cachinnans in the Azores Islands. Ecology and Conservation of Azorean Seabirds. Report of the 1989. Glasgow University expedition to the Azores Islands, Glasgow.

Harris, M.P. (1965) The food of some Larus gulls. Ibis, 107, 43-53.

Herrera, C.M. (1995) Plant-vertebrate seed dispersal systems in the Mediterranean: ecological, evolutionary, and historical determinants. Annual Review of Ecology and Systematics, 26, 705-727.

Hillström, L., Kilpi, M. \& Lindström, K. (1994) Diet of Herring Gulls, Larus argentatus, during chick rearing in the Gulf of Finland. Ornis Fennica, 71, 95-101.

Izhaki, I. \& Safriel, U.N. (1990) The effect of some Mediterranean scrubland frugivores upon germination patterns. Journal of Ecology, 78, 56-65.

Jordano, P. (1992) Fruits and frugivory. Seeds: the ecology of regeneration in plant communities (ed. by M. Fenner), pp. 105-156. CAB International, Wallingford, UK.

Jorge, M.A., Schuster, C. \& Acosta, C. (2000) Dieta primaveral de la gaviota patiamarilla, Larus cachinnans, en Alegranza, islas Canarias (Aves, Laridae). Vieraea, 28, 31-37.

Martín, A. \& Lorenzo, J.A. (2001) Aves del archipiélago canario. Lemus Editor, La Laguna.

Martín, A. \& Nogales, M. (1993) Ornithological importance of the Island of Alegranza (Canary Islands). Boletim Do Museu Municipal Do Funchal, 3, 167-179.

Meinertzhagen, R. (1955) The speed and altitude of bird flight (with notes on other animals). Ibis, 97, 81-117.

Moermond, G. \& Denslow, J.S. (1985) Neotopical avian frugivores: patterns of behavior, morphology, and nutrition, with consequences for fruit selection. Neotropical Ornithology (ed. by P.A. Buckley, M.S. Foster, E.S. Morton, R.S. Ridgely and F.G. Buckley), pp. 865-897. Ornithological Monographs 36, American Ornithologists' Union, Washington, DC.

Monaghan, P. (1977) The utilisation of urban resources by the Herring Gull Larus argentatus. PhD Thesis, University of Durham, Durham, UK. 
Morton, J.K. \& Hoggs, E.H. (1989) Biogeography of island floras in the Great Lakes. II. Plant dispersal. Canadian Journal of Botany, 67, 1803-1820.

Mougin, J.L. \& Stahl, J.C. (1981) Le regime alimentaire des Goélands Argentés Larus argentatus atlantis de l'île Selvagem Grande. Cyanopica, 1981, 43-48.

Mudge, G.P. \& Ferns, P.N. (1982) The feeding ecology of five species of gulls (Aves: Larini) in the inner Bristol Channel. Journal of Zoology London, 197, 497-510.

Munilla, I. (1997) Estudio de la Población y la Ecología Trófica de la Gaviota Patiamarilla en Galicia. PhD Thesis, Universidade de Santiago de Compostela, Spain.

Nogales, M., Delgado, J.D. \& Medina, F.M. (1998) Shrikes, lizards and Lycium intricatum (Solanaceae) fruits: a case of indirect seed dispersal on an oceanic island (Alegranza, Canaries). Journal of Ecology, 86, 866-871.

Nogales, M. \& Hernández, E.C. (1994) Interinsular variations in the spring and summer diet of the Raven Corvus corax in the Canary Islands. Ibis, 136, 441-447.

Nogales, M., Hernández, E.C. \& Valdés, F. (1999) Seed dispersal by common ravens Corvus corax among island habitats (Canarian Archipelago). Écoscience, 6, 56-61.

Nogales, M., Valido, A. \& Medina, F.M. (1995b) Frugivory of Plocama pendula (Rubiaceae) by the rabbit (Oryctolagus cuniculus) in xerophytic zones of Tenerife (Canary Islands). Acta Oecologica, 16, 585-591.

Nogales, M., Zonfrillo, B. \& Monaghan, P. (1995a) Diets of adult and chick Herring Gull Larus argentatus argenteus on Ailsa Craig, south-west Scotland. Seabirds, 17, 56-63.

Oro, D., Bosch, M. \& Ruíz, X. (1995) Effects of a trawling moratorium on the breeding success of the Yellow-legged gull Larus cachinnans. Ibis, 137, 547-549.

Porter, D.M. (1976) Geography and dispersal of Galapagos Islands vascular plants. Nature, 264, 745-746.

Proctor, V.W. (1968) Long-distance dispersal of seeds by retention in digestive tract of birds. Science, 160, 321-322.

Ridley, H.N. (1930) The dispersal of plants throughout the World. L. Reeve \& Co., Ashford.

Scharpf, R.F. (1970) Seed viability germination and radicle grow of dwarf mistletoe in California. USDA Forest Service Research, Paper PSW-59, CA.

Shilton, L.A., Altringham, J.D., Compton, S.G. \& Whittaker, R.J. (1999) Old world fruit bats can be long-distance seed dispersers through extended retention of viable seeds in the gut. Proceedings of the Royal Society of London B, 266, 219-223.

Silvertown, J.W. (1981) Seed size, life span, and germination date as coadapted features of plant life history. The American Naturalist, 118, 860-864.

Snow, B. \& Snow, D. (1988) Birds and Berries. T. \& A.D. Poyser, Calton.

Spaans, A.L. (1971) On the feeding ecology of the Herring Gull (Larus argentatus, Pont.) in the northern part of the Netherlands. Ardea, 59, 73-185. van Steenis, C.G.G.J. (1962) The land-bridge theory. Blumea, 11, 235-372.

Sueur, F. (1990) Regime alimentaire du Góeland Argenté Larus argentatus sur le littoral picard. L'Avocette, 14, 64-73.

Traveset, A. (1998) Effect of seed passage through vertebrate frugivores' guts on germination: a review. Perspectives in Plant Ecology, Evolution and Systematics, 1/2, 151-190.

Valdebenito, H.A., Stuessy, T.F. \& Crawford, D.J. (1990) A new biogeographic connection between islands in the Atlantic and Pacific Oceans. Nature, 347, 549-550.

Valido, A. (1999) Ecología de la Dispersión de Semillas por los Lagartos Endémicos Canarios (G. Gallotia, Lacertidae). PhD Thesis, Universidad de la Laguna, Tenerife, Spain.

Valido, A. \& Nogales, M. (1994) Frugivory and seed dispersal by the lizard Gallotia galloti (Lacertidae) in a xeric habitat of the Canary Islands. Oikos, 70, 403-411.

Verbeek, N.A.M. (1977) Comparative feeding ecology of herring gulls Larus argentatus and lesser black-backed gulls Larus fuscus. Ardea, 65, 25-41.

Whittaker, R.J. (1998) Island biogeography. Oxford University Press, Oxford.

Whittaker, R.J. \& Jones, S.H. (1994) The role of frugivorous bats and birds in the rebuilding of a tropical forest ecosystem, Krakatau, Indonesia. Journal of Biogeography, 21, 245-258.

Witt, H.H., Crespo, J., De Juana, E. \& Varela, J. (1981) Comparative feeding ecology of Audouins's Gull Larus audouini and the Herring Gull L. argentatus, in the Mediterranean. Ibis, 123, 519-526.

\section{BIOSKETCHES}

Manuel Nogales has been working on phenomena related to the evolutionary ecology of the terrestrial vertebrates in the Canary Islands. One of his main research interests is the seed dispersal systems in island environments.

Félix M. Medina has worked in animal-plant interaction and is now devoted to the conservation of the flora and fauna in La Palma Island.

Vicente Quilis has been working on raptors and seabirds in the Canaries and now his research interests include geographical information systems.

Mercedes González-Rodríguez has always worked on geographical information systems. 